\title{
Social Constructionism and Women Entrepreneurship: A Global Research Perspective
}

\author{
Albina Amin \\ M. Phil. Research Fellow, Faculty of Business Studies, Bangladesh University of Professionals, Bangladesh \\ *Corresponding Author: albinaamin01@gmail.com
}

Copyright $\bigcirc 2017$ by authors, all rights reserved. Authors agree that this article remains permanently open access under the terms of the Creative Commons Attribution License 4.0 International License

\begin{abstract}
This study aims to review the analysis of social constructivism approach and entrepreneurial activity of women entrepreneurs in global business market. The emergence of women entrepreneurship is not a new phenomenon all over the world. This paper measures the differences in the level of entrepreneurial activity analysis between countries from secondary data namely GEM 2007 report on women and entrepreneurship. The findings of this research are that when women are in action as business owners, it has direct association with social and economic development of a nation. It also shows how women entrepreneurship matters in global development. This paper is a combination of data analysis and creates two theoretical frameworks. Moreover, GEM 2016 report uses to analysis the SME contribution to nation's GDP.
\end{abstract}

Keywords Women, Social Constructionism, Women Entrepreneurship, Business, Global, Development

\section{Introduction}

The emergence of women entrepreneurship needs new direction all over the universe. Women involved in various small and medium businesses take on the challenge to line of work in a male-dominated society. Entrepreneurship is influenced by many factors; like economic development, culture, technological development education and so on. (Brush et al. [8]) Though this view of the entrepreneurial process is close to that underlying this paper, the view of social constructionism theorists can be accepted as a good research strategy. The outcome of women owned business is dependent on their innovative thoughts. The rationality of entrepreneurs is involved in the process on a national level. (Bouchikhi [6] Young [31]). This study links this idea of women entrepreneurship with social and economic development in a global scale.

\subsection{Objectives of the Study}

There are also some specific objectives such as:
- To measure differences in the level of entrepreneurial activity between countries using secondary data analysis

- To establish proper theoretical framework for women entrepreneurs in case of global prospective

\subsection{Methodology}

This article is basically both qualitative and quantitative research with descriptive data analysis. This study is based on two theories; social constructivism theory and entrepreneurship theory. It is also based on secondary data analysis from GEM 2007 report on women and entrepreneurship (Allen et al. [3]). There are two types of business owner described in this report; namely early stage business owner and established business owner for both sex group (Male and Female). To analyze these data more clearly, ANOVA test is used here. Moreover, this paper establishes two theoretical frameworks to give proper idea about the importance of women entrepreneurship. First theoretical framework gives the clue of how women entrepreneurs matter in social and economic development. Second theoretical framework provides the knowledge of how women entrepreneurs related with national income and ultimately global development. Finally, GEM 2016 report on entrepreneurship data is also used to analyze the contribution of SME to GDP.

\section{Central Question}

How women entrepreneurs lead us social and economic development in global context?

\subsection{Supporting Questions}

- Why social development and women entrepreneurship are related with each other?

- Why women entrepreneurs' success or failures affect social and economic development? 


\section{Rationale for Choosing the Topic}

There are some previously published articles showing the issues of problem and scope for women entrepreneurs in world. The Global Entrepreneurship Monitor (GEM) 2007 report on women and entrepreneurship is the fourth in a series of reports that provides comparable data for a cross national assessment of entrepreneurial activity in 41 countries whose economies symbolize more than 70 percent of the world's population and 93 percent of global GDP in 2007. It also includes reactions from 145,248 personalities, 49.9 percent of whom were women. According to the Global Entrepreneurship Monitor (GEM) 2007, women entrepreneurs make an important contribution to the development of the world economy, predominantly in low and middle-income countries. There are many ways to empower women; and furthermore entrepreneurial activity is critical for more sustainable economic and social development in all over the world.

The global sex ratio in the world was approximately 1,016 males to 1,000 females as of 2016. Since women account for half of any country's talent base, empowering their participation in the workforce greatly enhances productivity and higher economic growth. In fact, World Bank studies show that development strategies focusing on gender equality see stronger economic growth than gender-neutral strategies. Throughout the world, women represent a substantial, underutilized force for sustainable development. (World Bank, 2009). According to World Economic Forum's Human Capital Report 2016 a country's overall score on the World Economic Forum's Human Capital Index can roughly be taken as a percentage measure of the degree to which a country is successful in developing the full range of its human capital prospective (Peet [21], Bhatt [5]).

The following figure 1 explains the issue of rural diversification process and how this has an immediate influence on access to resources. The assets and activities of rural sector are shifting their own ways to institutions, social relations and organizations of urban area. The demand of women entrepreneurs are increasing from rural to urban area for better development. Usually, gender related challenges, nature of women entrepreneurs, restrictive government regulation are affecting success of women entrepreneurs (Ellis [12]).
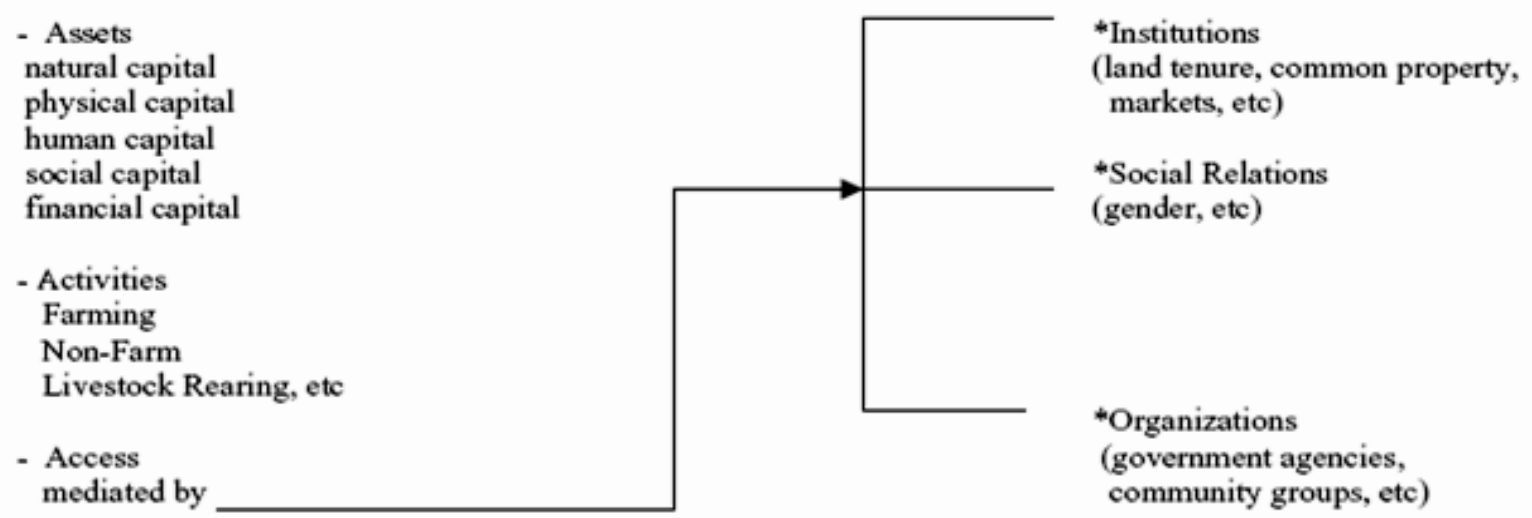

(Adapted from Ellis, F. (2000)," Rural Livelihoods and Diversity in Developing Countries," Oxford University Press, Oxford)

Figure 1. Rural livelihood and diversity in Developing Countries 
This study provides some advancing knowledge about the status of women entrepreneurship around the world with proper theoretical view and data analysis of GME 2007 and GME 2016 (Allen et al. [3], Herrington et al. [15]).

\section{Literature Review}

Initial research on entrepreneurship assumed that male and female entrepreneurs were generally the equivalent and there was no specific need for a separate investigation (Bruni et al. [7]). As a result, the sub-domain of women entrepreneurship did not develop as a significant area until the late 1990s to early 2000s (Jennings et al. [16]). Women entrepreneurs have become important global players in the entrepreneurial landscape (Pages [20]). Throughout the world, women represent a substantial, underutilized force for sustainable development. In Asia, for example, women are responsible for $50 \%$ of agricultural output, while nearly $80 \%$ of the agricultural labor in Africa market is female (Peet [21]).

Sinha [24] found in her investigation on "Developing Women Entrepreneurs in South Asia: Issues, Initiatives and Experiences" a preliminary definition set as "women running their own SMEs within the formal sector in South Asia". One of the major problems connected with spotting women entrepreneurs like "surrogate entrepreneurship" or "surrogate ownership" has been noted in some disquisitions, thus making the assignment of correctly catching women entrepreneurs truly wearisome (Sinha [24]). Sinha [24] and Ganesan [13], reports a high level of surrogate ownership among women entrepreneurs where in the name of the women, men (usually husbands or fathers or sons) were handling the business. Nearchou-Ellinas et al. [18] proposed that the status of women entrepreneurs in globe.

In an exploratory study, Shim et al. [23] compared Hispanic women- and men-owned businesses. The authors found that women-owned businesses were younger, had fewer employees, and had lower revenues. The authors speculated that the women business owners may not emphasize wealth creation as much as their male counterparts. The educated and experienced women are more interested in becoming entrepreneurs than non-educated and inexperienced women (Raman et al. [27]).

A specific social exercise contains definite forms of knowledge. The social constructivist methodology, the term "social constructivism" entered sociology through Berger and Luckmann's work The Social Construction of Reality. Society, the object of sociological inquiry, is perceived " as part of a human world, made by men". Thus, the reality of human life or socially constructed reality, rather than naturally given or merely taken for granted, as is the circumstance in old-fashioned positivist approaches. Moreover, Berger and Luckmann's "men'" were called "social performers." A key possessions of a social performer is his or her "agency," the ability to make judgments based on social involvement combined with the volume to manipulate community relations and to register others into his or her project based works. (Berger et al. [4], Verschoor et al. [28], Steins et al. [25]).

Sociological methodologies focus on structure and 'agentic' aspects of entrepreneurial manners; this has led to consideration of how signals from the environment may influence entrepreneurs. Not only has social constructionism materialized as an essential paradigm in which to recognize businesspersons but also theoretical constructs like social embeddedness have enabled one to develop insights into the social and structural relations in which entrepreneurs operate (Zimmer [32], Granovetter [14], Thornton [26]).

The social constructivist framework is related to integrate endogenous and exogenous environment in a proper manner (Bouchikhi [6]).This definition of human wellbeing is consistent with that envisioned by the capabilities approach (Sen [22], Nussbaum [19]). Social constructionists critique positivism and trait theory as presence 'essentialist' (Chell [10]). How male and female business owners construe each other (Wilson, et al. [30]). There is key relationship between social constructionism and the realism of women entrepreneurship (Lindgren et al. [17]). According to GME 2016 report the financial crisis of 2007 to 2008, which was followed by a significant global downturn from 2008 to 2012, has had a weighty outcome on the economic as well as entrepreneurial background (Herrington et al. [15]).

There is a research gap between how it is related that social constructivism theory to social realism theory for women entrepreneurs in global research prospective. Moreover, socio-economic development has direct link to women business owners for all over the world. This paper will try to locate many uncover issues with proper theoretical prospective.

\section{Theoretical Framework}

As following below two figure 2 and figure 3 , it is vibrant that entrepreneurship is related to internal and external environment in a proper manner (Ajzen [2], Chell [10]). 


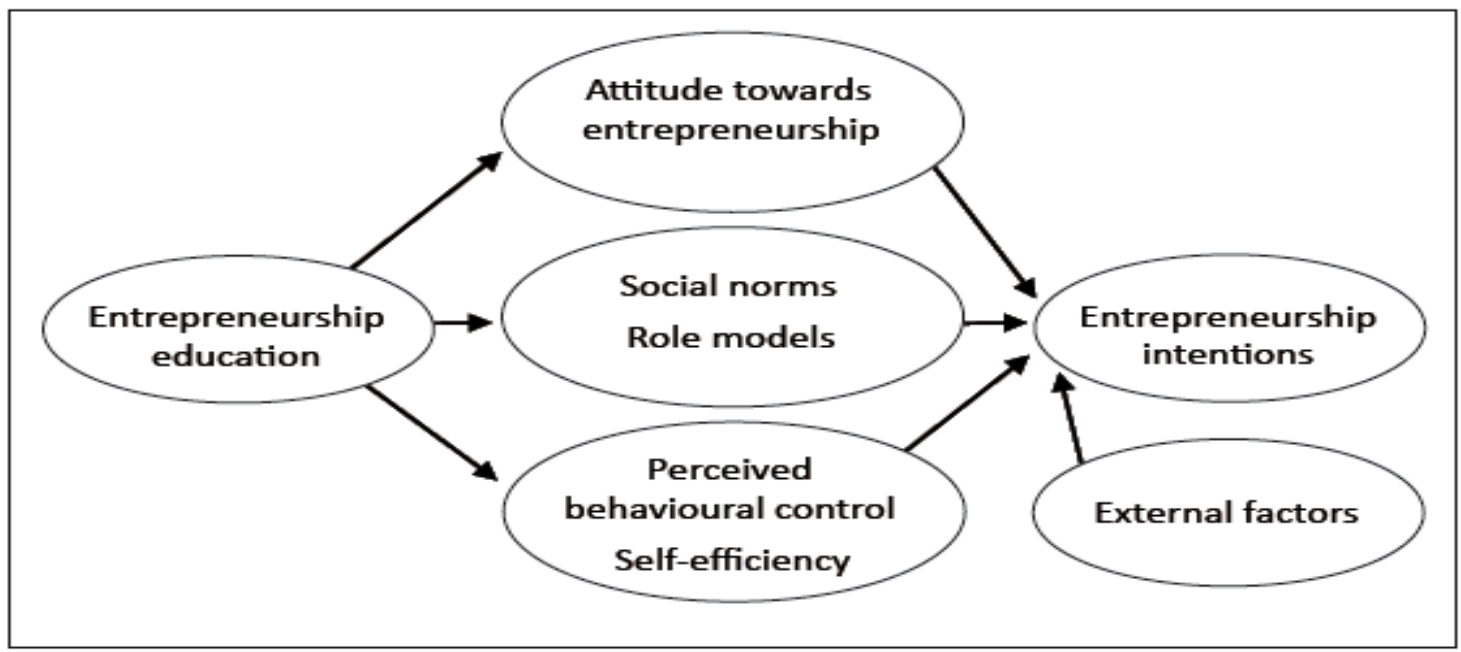

Source: Adapted from Ajzen, I. (1991). Theory of planned behaviour. Organizational Behaviour and Human Decision Processes, 50, 182. http://dx.doi.org/10.1016/07495978(91)90020-T

Figure 2. Social issues affecting way in entrepreneurship education to reality

This above figure 2 shows the relationship between entrepreneurship education, social norms and entrepreneurship intension with the view of internal and external factors. (Ajzen [2], Chell [10]).

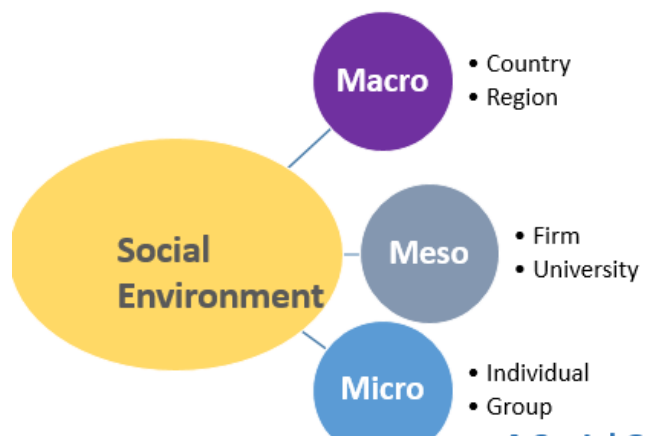

A Social Constructionist View (political \& social); Adopted from (Chell,2008)

Figure 3. A social constructivism view related to social environment

This above figure 3 exhibitions that there are three social environments associated in social showground. There are; (i) Macro environment, (ii) Meso environment, (iii) Micro environment.

In real world the social constructivism approach is shifted the idea of social realism. (Bouchikhi [6] Young [31]). Social realism is related with some demographic and environmental issues. These demographic and environmental factors are considered for the theoretical framework of this study based on suitability within global context. Accordingly the study of key factors affecting success of entrepreneurs can be grouped into two; namely demographic characteristics and environmental elements. (Chowdhury et al [11])

These demographic factors are identified with individual variables: For example, age, education and work experience. Environmental factors are considered with external elements variables: For example, Social, economic and political environment. At present days technology and information access to global business are playing significant role (Chowdhury et al [11]). 


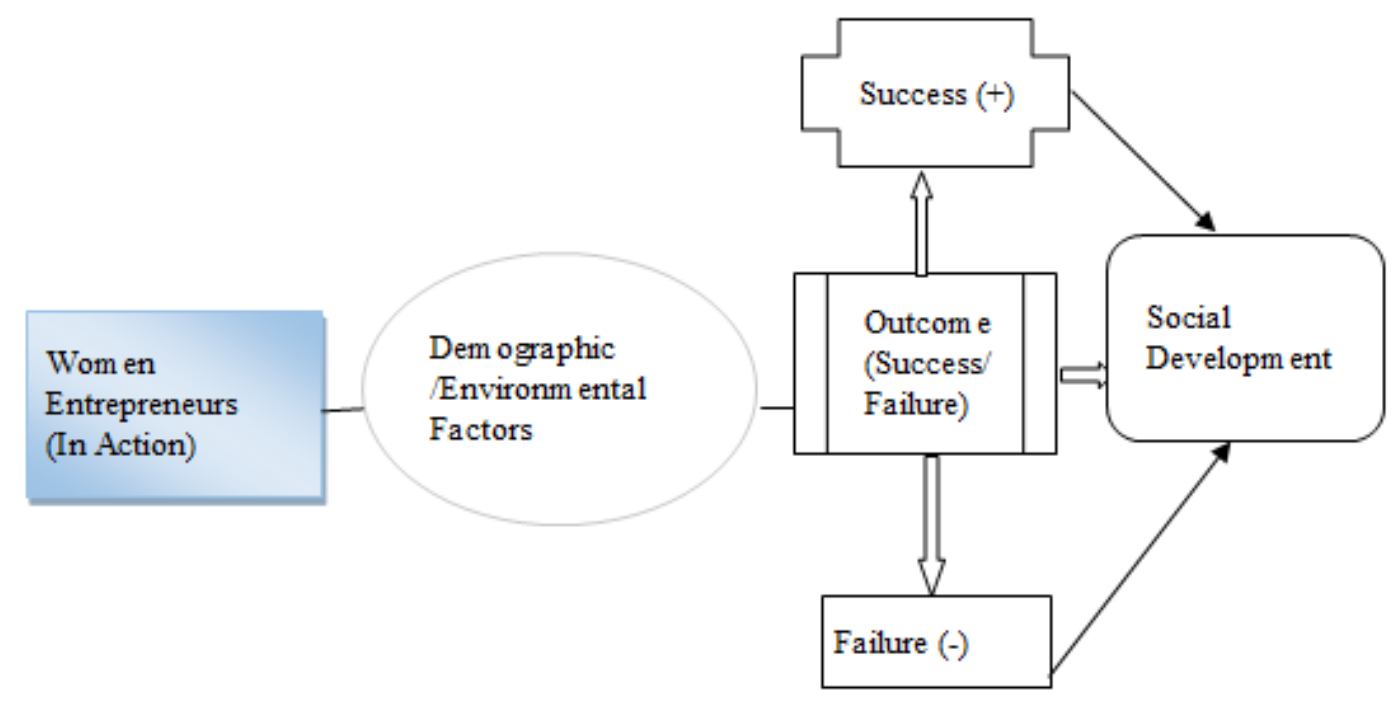

Figure 4. Theoretical framework of women entrepreneurs

When women entrepreneurs are in action they are facing two factors. After fulfilling these challenges from factors they are preparing to give some outcomes. No matter their outcome is success or failure, it has a direct link with social development of a nation (figure 4).

Welter et al. [29] display that women has contributed to economic development through setting up many activities, like manufacturing businesses and export-import businesses. Characteristically, female entrepreneurs are more likely to hire women, thus given that jobs not only for themselves but for other women. It promotes social development and provides shelter to poor women in a civil society. It is also working to reduce the effect of discrimination against women in the employment market. Furthermore, decreasing woman unemployment supports in the fight against trafficking of women, which is identified as one of the most critical issues in the Ukraine? Women entrepreneurs are playing as social role model to other women, which are leading the ultimate social development for developing and under-developing nations (Welter et al. [29], Allen et al. [3]).

\section{Data and Evidence}

The GEM research project shows assessment of entrepreneurial activity in 41 countries (Allen et al. [3]). This paper represents that data with three sided discussion.

\subsection{Data and Evidence 1}

Table 1. GEM 2007 report Data of three group of countries

\begin{tabular}{|c|c|}
\hline Three Group of countries & $\begin{array}{c}\text { \% of Women } \\
\text { Entrepreneurs }\end{array}$ \\
\hline Latin America and the Caribbean & 14.4 \\
\hline $\begin{array}{c}\text { European and Asian } \\
\text { low/middle-income }\end{array}$ & 7.62 \\
\hline high-income country group & 4.34 \\
\hline
\end{tabular}

From the above table three groups are distinguished for better interpreting the issue of women entrepreneurship. High-income country group of women are less active than any other two segment groups. This country group is basically addressed by the United States. Despite the masculine figures as Henry Ford, Donald Trump, and Bill Gates of popular images and early research on the subject, entrepreneurship is often seen as a form of empowerment for women. In the 1990s, women in the United States represented the fastest-growing segment of business owners. It is also calculated for $28 \%$ of all privately held firms, employing 9.2 million people, and contributing 2.3 trillion dollars in revenue to the United States (Center for Women's Business Research, 2001). GEM report 2007 found that particularly in low and middle-income countries, women entrepreneurs make an important contribution to the development of the national and international economy (Brush et al. [9], Allen et al. [3]).

\subsection{Data and Evidence 2}

From this following data shows the difference between male and female business owner around the world with three groups of country (Table 2). Here in table 2 there are two low and middle-income country groups, one is from Europe, Asia and other is from Latin America. The data presents that male and female business owners are more dynamic in Latin American group. On the other hand, high income countries are representing less interest in this case. This data is also gives proper evidence of male and female business owner's business outcome difference. In all three country income groups, a significant gender gap exists for both early stage entrepreneurial involvement and established business ownership, and this gender gap is greatest in the high-income nation group, regardless of type of activity. In the high-income group, overall men business owners are $16.08 \%$, almost twice than women $(7.91 \%)$. 
Table 2. Percentages of Entrepreneurial Activity across Country Group by Gender from GME Report 2007

\begin{tabular}{|c|c|c|c|c|c|c|}
\hline & \multicolumn{2}{|c|}{ Early Stage Entrepreneurial } & \multicolumn{2}{c|}{$\begin{array}{c}\text { Established Business } \\
\text { Owners }\end{array}$} & \multicolumn{2}{c|}{$\begin{array}{c}\text { Overall Business } \\
\text { Owners }\end{array}$} \\
\hline Country Groups & Male & Female & Male & Female & Male & Female \\
\hline Low/Middle Income (Europe/ Asia) & $11.70 \%$ & $7.62 \%$ & $8.19 \%$ & $4.62 \%$ & $19.89 \%$ & $12.24 \%$ \\
\hline $\begin{array}{c}\text { Low/Middle Income (Latin America/ } \\
\text { Caribbean) }\end{array}$ & $19.55 \%$ & $14.40 \%$ & $12.21 \%$ & $6.57 \%$ & $31.76 \%$ & $20.97 \%$ \\
\hline High-Income Countries & $8.17 \%$ & $4.34 \%$ & $7.91 \%$ & $3.57 \%$ & $16.08 \%$ & $7.91 \%$ \\
\hline
\end{tabular}

For analysis these above data, now hypothesis testing helps to reveal the truth about difference between male and female business owners for overall business owners.

Hypothesis (1)

$H_{0}$ : There is no significant difference of country group's performance of overall business owners

$H_{1}$ : There is significant difference of country group's performance of overall business owners

Hypothesis (2)

$H_{0}$ : There is no significant difference of sex group's performance of overall business owners

$H_{1}$ : There is significant difference of sex group's performance of overall business owners

Output (ANOVA test)

Table 3. ANOVA Testing for Overall Business Owners (Male and Female)

\begin{tabular}{|c|c|c|c|c|c|}
\hline Dependent Variable: Performance of Overall Business Owners \\
\hline Source & Type III Sum of Squares & df & Mean Square & F & Sig. \\
\hline Corrected Model & $337.450^{\mathrm{a}}$ & 3 & 112.483 & 79.426 & .012 \\
\hline Intercept & 1974.720 & 1 & 1974.720 & 1394.380 & .001 \\
\hline Sex & 118.015 & 1 & 118.015 & 83.332 & .012 \\
\hline Country_groups & 219.435 & 2 & 109.717 & & 77.473 \\
\hline Error & 2.832 & 2 & 1.416 & & \\
\hline Total & 2315.003 & 6 & & & \\
\hline Corrected Total & 340.282 & 5 & & & \\
\hline a. R Squared $=.992$ (Adjusted R Squared $=.979)$ & & & & \\
\end{tabular}

\section{Comments}

In case of country groups, $\mathrm{p}$ value $=0.013<0.05$ and rejected null hypothesis at $5 \%$ level of significant. There is significant difference of country group's performance of overall business owners.

In case of sex groups, $p$ value $=0.012<0.05$ and rejected null hypothesis at $5 \%$ level of significant. There is significant difference of sex group's performance of overall business owners.

Here, R Squared $=.992$ means that $99.2 \%$ variation of the dependent variable can be explained by the independent variables. In general, the higher R Squared, the better the model fits the data.

\subsection{Data and Evidence 3}

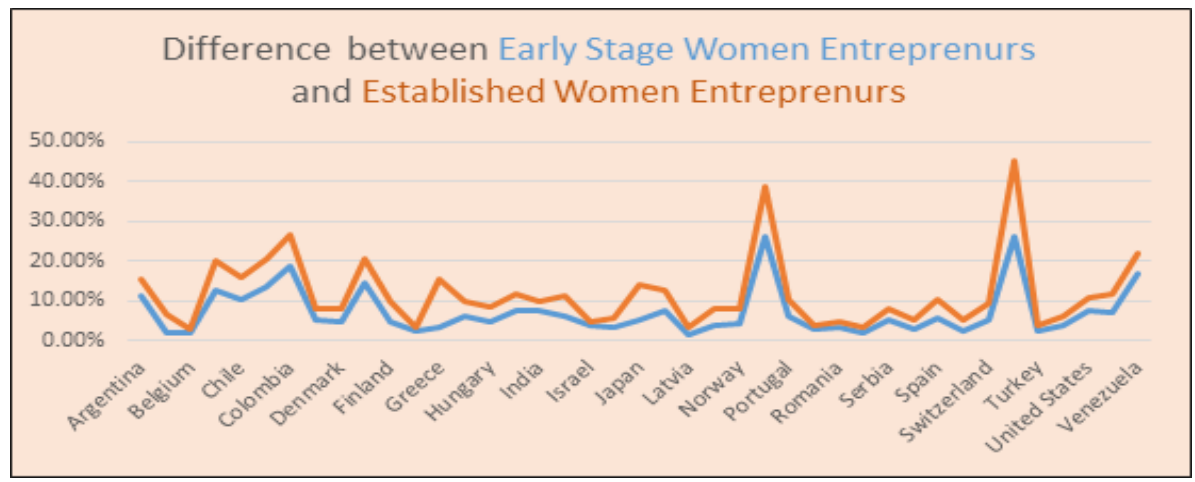

Graph 1. GEM 2007 report data of early stage and established women entrepreneurs of the world 
As we see from above graph, the difference between early stage women entrepreneurs and established women are not very significant. Early stage women entrepreneurs dependent on demographic factors; specially age. (Allen et al. [3]).

\section{Discussion and Data Analysis}

There are forty one countries participating in the GME 2007 Women's Report. They were divided into three country groups namely: (i) low/middle-income Europe and Asia, (ii) low/middle-income Latin America and Caribbean (iii) high-income group. The group is based on their per capita gross domestic product (GDP) and GDP growth rate (Allen et al. [3]).

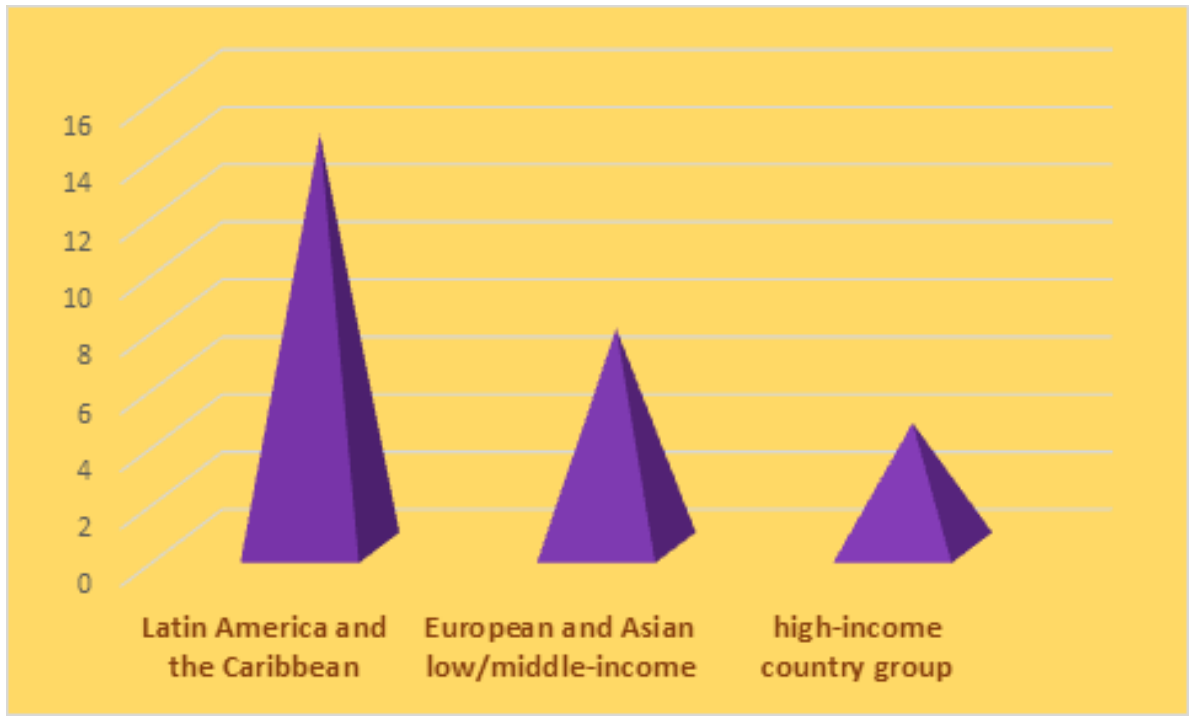

(GME 2007 Women's Report)

Graph 2. Data Analysis of Three country groups of Women Entrepreneurs

In this above graph 2, it is estimated that Latin America and the Caribbean group is contributing highest GDP growth rate of this issue. European and Asian group is moderately active as women entrepreneurs. High-income group is placed in a bottom level among all three groups.

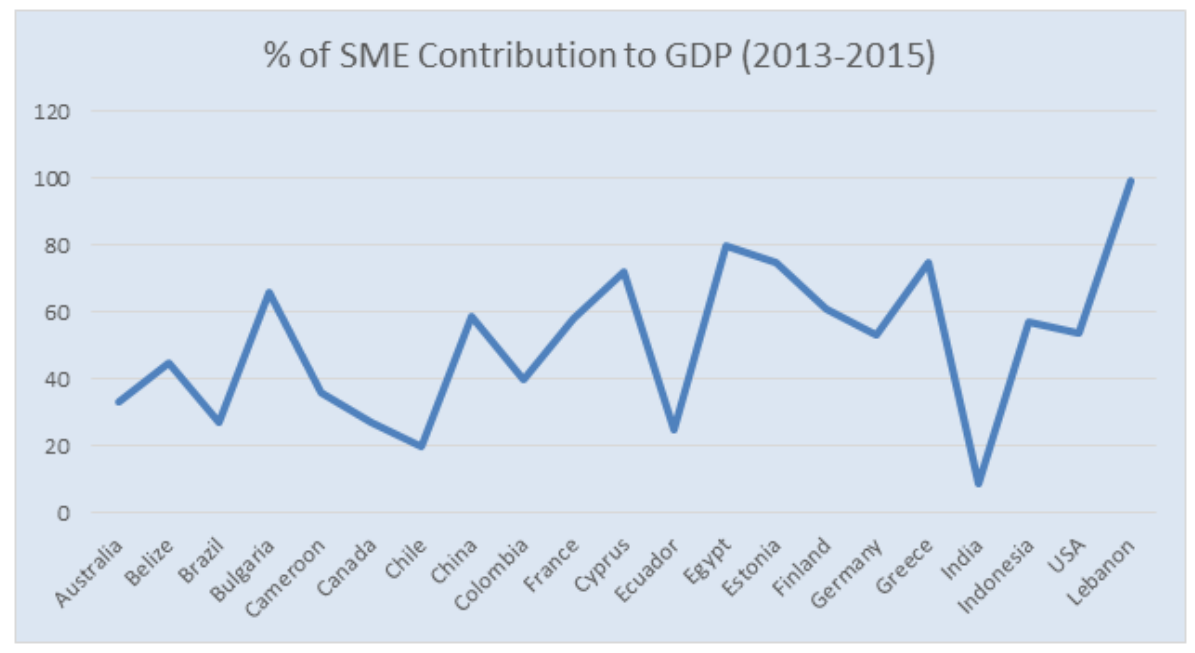

Graph 3. SME Contribution to GDP for 21 countries of the World. (Male and Female SME owner) (GME 2016-2017)

From this above graph 3, it represents that SME (Small and Medium Enterprise) has a great contribution to the GDP of a nation. Here, there are 21 countries data from GME 2016-2017(Herrington et al. [11]). The percentage of Lebanon, SME contribution to GDP is high 99\% (2015) and India is lowest only 9\% (2013). There are many social problems faced by Indian women; like gang rape, child marriage and high levels of trafficking and so on. According to World Economic Forum (WEF) Finland is the safest country on earth. The SME contribution to GDP of Finland is $61 \%$. It is evident that there is a correlation between entrepreneurial activity and social development of women. 
Relevance of Theoretical Framework

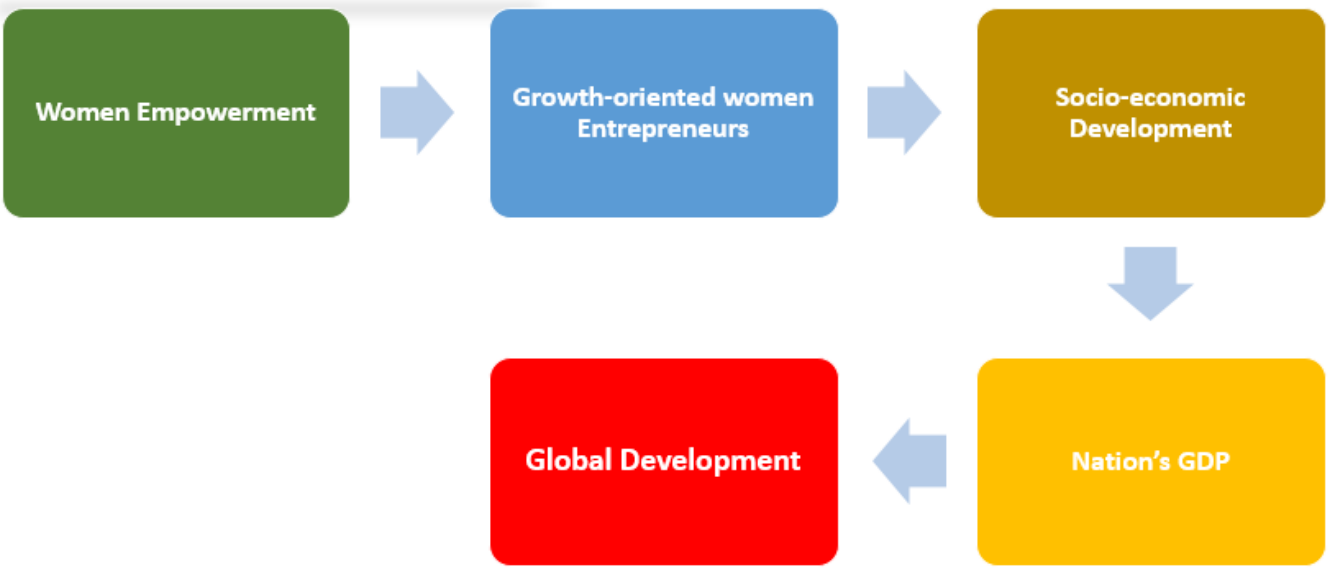

Figure 5. Relevance of theoretical framework of global prospective

\subsection{Relevance of Theoretical Framework}

Women entrepreneurship has attracted growing attention in recent years in sunlit of concrete evidence of its significance for financial growth and social development. The framework and modelling is an important step to discuss the link between women entrepreneurship and global development. Social constructivism theory provides an alternative representation of the entrepreneurial process. The outcome is determined by how women entrepreneurs overcome their challenges of demographic and environment factors. Women empowerment gives the idea of making independent women entrepreneurs. In figure 4 it is estimated that there is direct link between women entrepreneurs to social and economic development. They provide employment and producing possibilities both for themselves and for others, which promotes social development. All this economic contributes to reinforcement of the national economy. (Welter et al. [29], Allen et al. [3]). From economics point of view, the nation's economy directly gives the idea of a nation's GDP. Finally, national income has direct connection to international or global income, as many under developed countries are developing themselves by gaining more GDP. If any country can solved their own social and economic problem, they can establish good relation with other nations and join global market. This is the positive effects of globalization. So, it is theoretically proved that, nation's women entrepreneurship has direct link to global development. The following figure 5 , it is screening the proper justification and concept of applicability of theoretical framework.

\section{Concluding Remarks}

Academics and policy makers agree that entrepreneurs play a critical part in the expansion and well-being of their civilizations. The excursion of women entrepreneurs in business enterprises has not been a stress-free ride. It is demonstrated that the womankind entrepreneurship matters. They are creating and running businesses across a wide range of circumstances. Female entrepreneurship is an increasingly salient part of the economic makeup of many countries and is a key contributor to economic growth in low/middle-income countries, particularly in Latin America and the Caribbean. A gender gap and difference of country groups exists with respect to new venture creation and business ownership. The focus and potential of women entrepreneurial activity is quite varied worldwide. Women businesses exhibit many similar patterns to those of men but some differences are apparent. It can contribute towards economic development through their choice of being as women entrepreneurs. A clear difference can makes with the contribution of women entrepreneurs in the business world for country's own development. The under-developed countries can use this technique to rebuilt women entrepreneurs and gain more economic benefits through women. This ultimate gain from low and middle income countries gives directions of global development via women entrepreneurship.

\subsection{Suggestions for Further Study}

This paper offers a clear focus to prove that the women entrepreneurs make an important contribution to the development of the world economy. This paper also relates social constructivism theory to social realism theory for women entrepreneurship. The future paper may concerns development of the entrepreneurial education as a key field by providing conceptual tools for women and rethinking the debate about entrepreneurial education in a global research prospective.

\section{Acknowledgements}

The author acknowledges the support and 
encouragement received by Bangladesh University of Professionals, Dhaka for using its facilities in the preparation of this manuscript.

\section{REFERENCES}

[1] Ahl HJ. The making of the female entrepreneur: A discourse analysis of research texts on women's entrepreneurship (Doctoral dissertation, Internationella Handelshögskolan). 2002.

[2] Ajzen I. The theory of planned behavior. Organizational behavior and human decision processes. 1991 Dec 1; 50(2):179-211.

[3] Allen IE, Elam A, Langowitz N, Dean M. Global entrepreneurship monitor. 2006 report on women and entrepreneurship. 2007.

[4] Berger PL, Luckmann T. The social construction of reality: A treatise in the sociology of knowledge. Penguin UK; 1991 Mar 28.

[5] Bhatt A. Global Gender Parity Insights from the World Economic Forum's Gender Gap Report. Chicago Policy Review (Online). 2017 Mar 29.

[6] Bouchikhi H. A constructivist framework for understanding entrepreneurship performance. Organization Studies. 1993 Jul;14(4):549-70.

[7] Bruni A, Gherardi S, Poggio B. Entrepreneur-mentality, gender and the study of women entrepreneurs. Journal of Organizational Change Management. 2004 Jun 1; 17(3):256-68.

[8] Brush CG, Brush CG. Growth-oriented women entrepreneurs and their businesses: A global research perspective. Edward Elgar Publishing; 2006.

[9] Brush C, Carter NM, Gatewood E J, Greene PG, Hart M. The Diana Project: Women business owners and equity capital: The myths dispelled; 2001

[10] Chell E. The entrepreneurial personality: A social construction. Routledge; 2008 Jun 30.

[11] Chowdhury MS, Alam Z, Arif MI. Success factors of entrepreneurs of small and medium sized enterprises: Evidence from Bangladesh. Business and Economic Research. 2013 Jul 1;3(2):38.

[12] Ellis F. Rural livelihoods and diversity in developing countries. Oxford university press; 2000 Jun 29.

[13] Ganesan, S. Status of Women Entrepreneurs in India. New Delhi. Kanishka Publications. 2003.

[14] Granovetter M. Economic action and social structure: The problem of embeddedness. American journal of sociology. 1985 Nov 1; 91(3):481-510.

[15] Herrington M, Kew P. GEM 2016/17 global report.

[16] Jennings JE, Brush CG. Research on women entrepreneurs: challenges to (and from) the broader entrepreneurship literature?. Academy of Management Annals. 2013 Jun 1; 7(1):663-715.

[17] Lindgren M, Packendorff J. Social constructionism and entrepreneurship: Basic assumptions and consequences for theory and research. International Journal of Entrepreneurial Behavior \& Research. 2009 Jan 30; 15(1):25-47.

[18] Nearchou-Ellinas L, Kountouris IS. Women entrepreneurs in Cyprus: a new dynamic in Cyprus economy. Women in Management Review. 2004 Sep 1; 19(6):325-32.

[19] Nussbaum M. Capabilities as fundamental entitlements: Sen and social justice. Feminist economics. 2003 Jan $1 ; 9(2-3): 33-59$.

[20] Pages, Erik R. The changing demography of entrepreneurship. Local Economy (20.1) 2005: 93-97.

[21] Peet R. Unholy trinity: the IMF, World Bank and WTO. Zed Books Ltd.; 2009 Nov 16.

[22] Sen, Amartya K. Gender and Cooperative Conflicts. in Irene Tinker, ed. Persistent Inequalities. pp. 123-49. Oxford: Oxford University Press; 1990.

[23] Shim S, Eastlick MA. Characteristics of Hispanic female business owners: an exploratory study. Journal of Small Business Management. 1998 Jul 1; 36(3):18.

[24] Sinha S. Developing women entrepreneurs in South Asia: Issues, initiatives and experiences. United Nations, Economic and Social Commission for Asia and the Pacific; 2005 .

[25] Steins NA, Edwards VM. Collective action in common-pool resource management: The contribution of a social constructivist perspective to existing theory. Society \& Natural Resources. 1999 Aug 1; 12(6):539-57.

[26] Thornton PH. The sociology of entrepreneurship. Annual review of sociology. 1999 Aug; 25(1):19-46.

[27] Raman K, Anantharaman R N, Jayasingam S. Motivational factors affecting entrepreneurial decision: A comparison between Malaysian women entrepreneurs and women non entrepreneurs. Communications of the IBIMA. 2008; 2(12):85-9.

[28] Verschoor GM. Tacos, Tiendas and Mezcal: An actor-network perspective on small-scale entrepreneurial projects in Western Mexico. Verschoor; 1997.

[29] Welter F, Smallbone D, Isakova NB, editors. Enterprising women in transition economies. Ashgate Publishing, Ltd.; 2006.

[30] Wilson F, Tagg S. Social constructionism and personal constructivism: Getting the business owner's view on the role of sex and gender. International Journal of Gender and Entrepreneurship. 2010 Mar 30; 2(1):68-82.

[31] Young M. Bringing knowledge back in: From social constructivism to social realism in the sociology of education. Routledge; 2007 Oct 19.

[32] Zimmer C. Entrepreneurship through social networks. The art and science of entrepreneurship. Ballinger, Cambridge, MA. 1986:3-23. 